\title{
Timing of digestion, absorption and assimilation in octopus species from tropical (Octopus maya) and subtropical-temperate (O. mimus) ecosystems
}

\author{
Marcela Linares ${ }^{1}$, Claudia Caamal-Monsreal ${ }^{2}$, Alberto Olivares ${ }^{3}$, Ariadna Sánchez ${ }^{2}$, \\ Sergio Rodríguez ${ }^{4}$, Oscar Zúñiga ${ }^{3}$, Cristina Pascuall ${ }^{2}$, Pedro Gallardo ${ }^{2}$, Carlos Rosas ${ }^{2, *}$ \\ ${ }^{1}$ Posgrado en Ciencias del Mar y Limnología, Universidad Nacional Autónoma de México, Avenida Universidad 3000, \\ Distrito Federal 04510, México \\ ${ }^{2}$ Unidad Académica Sisal, Facultad de Ciencias, Universidad Nacional Autónoma de México, Puerto de Abrigo s/n Sisal \\ Yucatán, México \\ ${ }^{3}$ Departamento de Ciencias Acuáticas y Ambientales, Facultad de Ciencias del Mar y Recursos Biológicos, \\ Universidad de Antofagasta, Chile \\ ${ }^{4}$ Unidad Académica Sisal, Facultad de Química, Universidad Nacional Autónoma de México, Puerto de Abrigo s/n Sisal, \\ Yucatán, México
}

\begin{abstract}
Culture of octopuses is still in an experimental stage due to a lack of knowledge about their digestive physiology. This study aimed to determine the temporality of nutrient digestion, absorption and assimilation in 2 species of octopus: the tropical Octopus maya (habitat temperature 22 to $26^{\circ} \mathrm{C}$ ) and the subtropical-temperate $O$. mimus $\left(15\right.$ to $\left.21^{\circ} \mathrm{C}\right)$. In both species, the chyme volume displayed 2 peaks over time along the digestive tract: one at the beginning of digestion and a second at the end of the digestion process. These phases were observed in gastric juice (GJ) enzymes, in the flow of nutrients in the digestive gland (DG), in the appearance of metabolites in the hemolymph, and in muscle protein and glycogen levels. The soluble nutrient flow throughout the digestive tract into the DG was similar in both species. However, intracellular digestion was different in $O$. mimus compared to O. maya; lipids were mobilized faster than proteins in $O$. mimus, whereas proteins were mobilized faster than lipids in $O$. maya. This suggests that at low temperatures, the mobilization of lipids could be a biological priority due to their role in membrane protection. In addition, $O$. mimus displayed more digestive enzyme activity in the GJ and DG compared with $O$. maya, suggesting that adaptive differences may be related to environmental temperatures.
\end{abstract}

KEY WORDS: Octopus maya $\cdot$ Octopus mimus · Digestive physiology $\cdot$ Digestion timing $\cdot$ Enzyme activity · Gastric juice $\cdot$ Free amino acid pool $\cdot$ Hemolymph

\footnotetext{
*Corresponding author: crv@ciencias.unam.mx
}

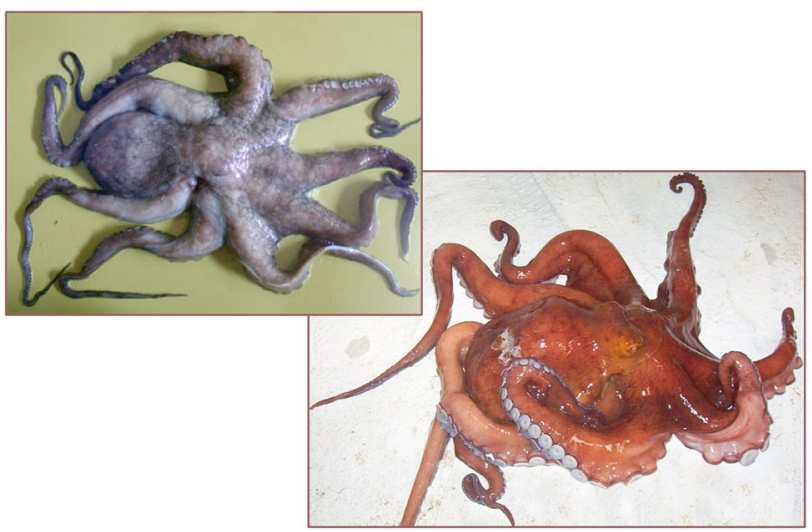

Top left: Octopus mimus from the Antofagasta coastal zone, Chile (subtropical environment); bottom right: $O$. maya from the continental shelf of the Yucatán Peninsula (tropical).

Photos: A. Olivares \& C. Rosas

\section{INTRODUCTION}

Proteins are the main metabolic substrate for cephalopods. They are characterized by a low oxygen:nitrogen ratio and are derived from a natural diet based mainly on crustaceans, mollusks and fish (Segawa \& Hanlon 1988, Olivares et al. 1996, Carrasco \& Guisado 2010, Rosas et al. 2011). Roura et al. (2012) demonstrated the importance of crustaceans in the diet of octopods, reporting 19 species of crus-

() The authors 2015. Open Access under Creative Commons by Attribution Licence. Use, distribution and reproduction are unrestricted. Authors and original publication must be credited. 
taceans in the diet of wild Octopus vulgaris paralarvae. O. maya and $O$. mimus are not exceptions; these carnivorous species also use protein as their main energy source (Van Heukelem 1977, Rosas et al. $2007 a, b)$. O. maya and O. mimus adapt well to captivity, eat freeze-dried diets, and can reach high market value (Zuñiga et al. 1995, Salas et al. 2006), thus making both species good candidates for marine aquaculture (Iglesias et al. 2014). However, one of the main bottlenecks in octopus aquaculture is the lack of elaborated diets that cover their nutritional requirements (Aguado Giménez \& García García 2002, Prato et al. 2010, Villanueva et al. 2014). Recently, a semi-humid paste made with squid and crab meat was created as a successful diet for $O$. maya, and is the only diet that has been tested in octopus juveniles (Martínez et al. 2014). In most cases, octopus culture is at an experimental phase given the general lack of knowledge about their digestive physiology and the way proteins are digested. Protein digestion is a key aspect of digestibility in both invertebrates and vertebrates, and is an important determinant of the suitability of diets.

Digestion in cephalopods, and particularly in octopods, begins in the buccal mass (Boucaud-Camou \& Boucher-Rodoni 1983). As the prey is broken down mechanically, the posterior salivary glands secrete alkaline enzymes and the food then passes through the esophagus to the anterior stomach (crop) (Nixon 1979, 1980, Boucaud-Camou \& Boucher-Rodoni 1983). The food is further broken down in the crop, where it combines with acidic enzymes secreted by the digestive gland (DG) to form the chyme, initiating extracellular digestion (Morishita 1972, Bocaud-Camou \& Boucher-Rodoni 1983). The chyme passes to the stomach (St), and from there to the caecum (Ce) where in some cephalopods (e.g. Sepia officinalis and $O$. vulgaris) a small quantity of chyme is absorbed (Boucaud-Camou \& Boucher-Rodoni 1983). The chyme then moves directly from the Ce towards the DG, where intracellular digestion is carried out (Boucaud-Camou \& Boucher-Rodoni 1983). The DG is the largest gland in the cephalopod body and performs many functions, such as synthesis and secretion of digestive enzymes, re-absorption and metabolism of nutrients, and synthesis and storage of glycogen (Boucaud-Camou et al. 1976, Rosa et al. 2005b, Martínez et al. 2011a,b).

Digestive enzymes in $O$. vulgaris are released by apocrine secretion into the lumen of the DG tubules where they are sent as zymogens to the digestive tract (Budelmann et al. 1997, Semmens 2002, Martínez et al. 2011a). Most of these enzymes are acidic, and are present in secretory lysosomes in octopods (e.g. O. vulgaris and O. maya), and in the loliginid squid Sepioteuthis lessoniana (Morishita 1972, Semmens 2002, Martínez et al. 2011b). Depending on the species, the number of secretory lysosomes increases several times throughout the feeding process, suggesting that extracellular digestive enzymes are released in pulses. Therefore, the release and activity of digestive enzymes may occur in response to the phase of the digestive cycle. In O. maya, the diameter and density of secretory lysosomes in the DG change according to the postprandial period, increasing significantly between 2 and $4 \mathrm{~h}$ after feeding (Martínez et al. 2011b). In O. vulgaris, the presence of food in the crop activates the DG and the secretion of enzymes in the posterior salivary glands (Best \& Wells 1984).

In studies examining the chemical composition of 33 marine species, Cerezo Valverde et al. (2012, 2013) concluded that arginine (Arg) and leucine (Leu) were the limiting amino acids (AA) in most of the analyzed samples of $O$. vulgaris diet. Thus, the authors concluded that the inclusion of those AA in crustacean-based diets could benefit the culture of $O$. vulgaris. A better understanding of AA kinetics during the digestive process may also help to elucidate how the type of diet modulates the use of proteins and octopus growth.

Perez-Losada et al. (2002) suggested that $O$. mimus and $O$. maya belong to a different confamilial genus than $O$. vulgaris due to allopatric speciation associated with the geomorphologic lifting of Central America. Apparently, the formation of the Panama Isthmus during the late Miocene and early Pliocene interrupted the genetic flow between Pacific and Atlantic octopus populations, separating populations and allowing speciation to occur (Porta 2003). Indeed, O. mimus is distributed from northern Peru (Tumbes) to central Chile (Bahía de San Vicente) where temperatures are lower $\left(15\right.$ to $21^{\circ} \mathrm{C}$; Uriarte et al. 2012) than the temperatures within the geographic range of $O$. maya $\left(22\right.$ to $26^{\circ} \mathrm{C}$; Noyola et al. 2013). Even though both species could have the same evolutionary origin and a similar mechanism of digesting food, the way in which environmental conditions modulate the use of the ingested nutrients may differ. Hence, the nutritional requirements for each species may be related to the specific environmental conditions in their respective habitats.

This study aimed to describe the temporality of nutrient digestion, absorption and assimilation in $O$. maya and $O$. mimus fed with crab. This approach allowed us to evaluate the dynamics of nutrient use along the digestive tract, including how the nutrients 
are transported and stored for use as a source of energy and growth. Using O. maya and O. mimus as model species, this study proposes temporal patterns of digestive physiology that may extend to other tropical and subtropical-temperate octopods.

\section{MATERIALS AND METHODS}

\section{Octopus collection}

Wild Octopus maya adults $(\mathrm{n}=66 ; 810 \pm 116 \mathrm{~g}$ wet weight [ww]) were caught in Sisal harbor (Yucatán, México) using artisan lines without hooks and with fresh crabs as bait. Captured octopuses were transported to the laboratory, located $300 \mathrm{~m}$ inland, in a 400 l circular tank filled with sea water. In the laboratory, animals were placed individually into $80 \mathrm{l}$ green tanks containing sea water. All individuals were acclimated for $12 \mathrm{~d}$ at $28 \pm 1^{\circ} \mathrm{C}, 34$ PSU salinity, dissolved oxygen levels $>5.5 \mathrm{mg} \mathrm{l}^{-1}$ and $\mathrm{pH} 8.2 \pm 0.1$; a $10 \mathrm{~cm}$ diameter PVC tube was offered as shelter. During the acclimation period, octopus were fed frozen crabs Callinectes sapidus at a ratio of $4 \% \mathrm{~d}^{-1}$ of the octopus ww. A $12 \mathrm{~h}$ light:12 h dark photoperiod was maintained during the experiments.

Wild O. mimus ( $\mathrm{n}=27 ; 1048 \pm 180 \mathrm{~g}$ ww) were caught by SCUBA divers in the Coloso zone, Antofagasta, Chile $\left(23^{\circ} 45^{\prime} 29^{\prime \prime} \mathrm{S}, 70^{\circ} 27^{\prime} 41^{\prime \prime} \mathrm{W}\right)$. Animals were transported individually in sea water and placed in $3.8 \mathrm{~m}^{3}$ tanks at a density of 3 ind. $\mathrm{m}^{-3}$. Tanks were covered with a black mesh to attenuate light by $50 \%$; an open-flow sea water system maintained the temperature at $14 \pm 2^{\circ} \mathrm{C}$, oxygen levels $>6 \mathrm{mg} \mathrm{l}^{-1}$ and $\mathrm{pH}>8$. Animals were fed frozen crabs Cancer setosus ad libitum for $3 \mathrm{~d}$ before proceeding with the sampling.

\section{Experimental design}

A total of 61 O. maya individuals were sampled at 9 different time points: 0 (fasting), 20, 40, 80, 120, $160,240,360$ and $480 \mathrm{~min}$ after feeding. O. mimus specimens $(\mathrm{n}=28)$ were sampled at 8 time points: $0,30,90,150,210,270,330$ and $390 \mathrm{~min}$ after feeding (see Table 1 for details of the number sampled at each time). The times after feeding at which the animals were sampled were determined from previous experiments with both species, and by taking into account that the digestive process may be faster at the beginning in the tropical O. maya than in the temperate O. mimus (Carrasco \& Guisado 2010,
Martínez et al. 2012). Crabs were deposited in the tanks and octopuses were left with the prey for 20 to $30 \mathrm{~min}$, which was sufficient time for them to ingest the crabs (Martínez et al. 2012). Crab carapaces were then retrieved and octopuses were held in their tanks until the sampling time.

As an ethical consideration (Mather \& Anderson 2007) and to ensure the welfare of octopuses during manipulation (Moltschaniwskyj et al. 2007), each animal was immersed in seawater at $15^{\circ} \mathrm{C}$ (for $O$. maya) and at $4^{\circ} \mathrm{C}$ (for O. mimus) for 3 min to reduce their metabolism (anesthesia) before dissection. Octopuses were covered with a clean piece of cloth, the arms of the animal were positioned at rest and the mantle exposed for surgery. The hemolymph was sampled and anesthetized animals were immediately euthanized by cutting the brain behind the eyes to minimize suffering.

\section{Hemolymph samples, metabolites and amino acids}

Approximately 2 to $3 \mathrm{ml}$ of hemolymph was obtained from each animal using a pre-chilled catheter $(24 \mathrm{G} \times 3 / 4$ inch and $22 \mathrm{G} \times 1$ inch Punzocat) inserted into the dorsal artery after the octopus was dried with a paper towel. The individual weight of each animal $( \pm 0.05 \mathrm{~g})$ was recorded. The hemolymph was centrifuged $\left(8000 \times g, 4^{\circ} \mathrm{C}\right)$ for $5 \mathrm{~min}$ to obtain plasma, which was placed immediately in liquid nitrogen and stored at $-40^{\circ} \mathrm{C}$ until analysis. Commercial kits were used for the determination of acylglycerols (AG) (Ellitech TGML5415), cholesterol (Chol) (Ellitech CHSL5505) and glucose (Ellitech GPSL0507). Plasma was further diluted 1:300 for soluble protein determination using a commercial kit (Bio-Rad; Cat. 5000006) based on the Bradford (1976) method. Determinations were adapted to a microplate using $20 \mu \mathrm{l}$ of plasma and $200 \mu \mathrm{l}$ of enzyme chromogen reagent. Absorbance was recorded using a microplate reader (Benchmark Plus; Bio-Rad) and concentrations were calculated from a standard substrate solution.

The free AA content (g AA per $100 \mathrm{~g}$ protein) of hemolymph was determined by ethanol extraction of lyophilized hemolymph $(80 \% \mathrm{v} / \mathrm{v}$; Dooley et al. 2002). Solids were diluted with $20 \mathrm{mM} \mathrm{HCl}$ to obtain a concentration of $1 \mathrm{mg} \mathrm{ml}^{-1}$. AA profiles were determined following the Waters AccQ-Tag ${ }^{\mathrm{TM}}$ procedure as follows: samples were (1) filtered $(0.45 \mu \mathrm{m})$ and maintained at $-20^{\circ} \mathrm{C}$ until used, (2) derivatized using the Waters system AccQ-Tag ${ }^{\mathrm{TM}}$ and (3) chromatographed through a reverse phase $(3.9 \times 150 \mathrm{~mm})$ $4 \mu \mathrm{m}$ Nova Pak ${ }^{\mathrm{TM}} \mathrm{C}-18$ column, using a water- 
acetonitrile gradient recommended by the Waters AccQ-Tag ${ }^{\mathrm{TM}}$ methodology (Milford), in a Waters ${ }^{\mathrm{TM}}$ HPLC system with a 2475 fluorescence detector (excitation and emission wavelengths 250 and $395 \mathrm{~nm}$, respectively). Analyses were conducted at a constant temperature of $39^{\circ} \mathrm{C}$. HPLC signal calibration and standard curves were obtained by using an AA standard solution at 3 different concentrations containing 18.75 to $150 \mathrm{pmol}$ of each AA. These results were taken with caution given that methionine is partially destroyed by acid hydrolysis.

\section{Chyme digestive tract sampling and enzymatic activity}

The digestive tracts of both species were completely extracted and separated into crop, $\mathrm{St}, \mathrm{Ce}$ and DG using surgical clamps to avoid mixing the digestive contents of each section. DG sections were dissected, frozen in liquid nitrogen and stored at $-40^{\circ} \mathrm{C}$ until analysis. At the same time, the volume of the chyme contained in each section was measured $( \pm 1 \mathrm{ml})$, immediately frozen in liquid nitrogen and stored at $-40^{\circ} \mathrm{C}$ until analysis. Samples of $O$. mimus were freeze dried and stored at $-20^{\circ} \mathrm{C}$ until analysis.

Gastric juice (GJ) enzymatic activity was quantified in the chyme from each section of the digestive tract obtained throughout the digestion process. Chyme samples were thawed at $24^{\circ} \mathrm{C}$ (laboratory temperature) and centrifuged $\left(8000 \times g_{;} 4^{\circ} \mathrm{C}\right)$ for $5 \mathrm{~min}$; the supernatant was used to determine digestive enzyme activity and soluble protein. The frozen DG sections were homogenized at $4^{\circ} \mathrm{C}$ in $500 \mu$ icecold, pyrogen-free water. Homogenates were immediately used for enzymatic analysis. Total soluble protein was evaluated with the Coomassie blue dye method (Bradford 1976) using serum bovine albumin as the standard.

Activity of total acidic proteinases was evaluated using Stauffer's universal buffer (Stauffer 1989) prepared at pH 6 for GJ samples and pH 3 for DG samples (Martínez et al. 2011a). Acidic proteinase and alkaline proteinase activities were assayed using hemoglobin $(1 \%)$ or casein $(1 \%)$ as the substrate (Anson 1938). Briefly, $20 \mu \mathrm{l}$ of the enzyme extract (dilution 1:10) was mixed with $0.5 \mathrm{ml}$ of buffer, and $0.5 \mathrm{ml}$ of freshly prepared substrate in buffer at the corresponding $\mathrm{pH}$ ( 6 or 3 for acidic proteinases; 8 for alkaline proteinases), and incubated for $10 \mathrm{~min}$ at $40^{\circ} \mathrm{C}$ for GJ samples and $45^{\circ} \mathrm{C}$ for DG samples. The reaction was stopped by adding $0.5 \mathrm{ml}$ of $20 \%(\mathrm{w} / \mathrm{v})$ trichloroacetic acid (TCA) and cooling for $15 \mathrm{~min}$ at $4^{\circ} \mathrm{C}$. The precipitated undigested substrate was centrifuged for $15 \mathrm{~min}$ at $13370 \times \mathrm{g}$. The absorbance of the supernatants was measured spectrophotometrically (Genesys 10UV; Thermo Scientific) at $280 \mathrm{~nm}$ against the substrate without the enzyme extract (blank). All determinations were done in triplicate and included blanks, which consisted of buffer, substrate, and TCA without enzyme extracts. Blanks were incubated as previously described.

For both acidic and alkaline proteinases, one unit of enzymatic activity was defined as the change in absorbance $\mathrm{min}^{-1} \mathrm{mg}^{-1}$ protein of the enzyme used in this assay (UI $\mathrm{mg}^{-1}$ protein). All enzymatic evaluations were also expressed as a percentage of the maximum activity $(100 \%)$ registered in a particular sampling time along the digestive process.

\section{Digestive gland and muscle metabolites}

DG samples and 2 arms of each sampled animal were frozen in liquid nitrogen and then stored at $-80^{\circ} \mathrm{C}$ until analysis. From DG samples, soluble protein, AG, Chol, glucose and glycogen were measured. Muscle soluble protein and glycogen were evaluated from the octopus arms. Total soluble protein was evaluated with the Coomassie blue dye method (Bradford 1976) adapted to a microplate method using a commercial chromogen reagent (Bio-

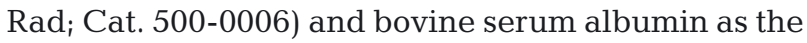
standard. The same commercial kits described above were used for glucose, AG and Chol measurements. Determinations were adapted to a microplate using $10 \mathrm{ml}$ DG extract and GJ (dilution 1:10) and $200 \mu \mathrm{l}$ of the chromogen reagent. Absorbance was recorded on a microplate reader and the concentrations were calculated from a standard substrate solution.

Glycogen was determined using the method described by Carroll et al. (1956). Glycogen in the DG and arms was extracted with $5 \%$ TCA and determined through the reaction with sulfuric acid and phenol. Sections of the DG and arms were weighed (20 to $30 \mathrm{mg}$ ) and homogenized in TCA for $2 \mathrm{~min}$ at $4550 \times \mathrm{g}$, then $100 \mu \mathrm{l}$ of supernatant was pipetted into a tube and mixed with $500 \mu \mathrm{l}$ of $95 \%$ ethanol. Tubes were placed in an oven at $37^{\circ} \mathrm{C}$ for $3 \mathrm{~h}$. After precipitation, the tubes were centrifuged at $4550 \times g$ for $15 \mathrm{~min}$. The supernatant was discarded, leaving the glycogen as a pellet. Glycogen was dissolved by adding $1 \mathrm{ml}$ concentrated sulfuric acid and $200 \mu \mathrm{l}$ of $5 \%$ phenol $_{i} 200 \mu \mathrm{l}$ was then transferred from the solution to a microplate and read at $490 \mathrm{~nm}$ on an ELISA plate reader (Bio-Rad 550). The total weight of the DG was also recorded. 


\section{Statistical analyses}

Assumptions of normality and homogeneity of variances were verified using the KolmogorovSmirnov and Levene tests, respectively. Data in percentages were transformed using the arcsin transformation (Zar 1999). A 1-way analysis of variance (ANOVA) was used to test if there were statistically significant differences $(p<$ 0.05 ) between sampling times for each biochemical parameter measured. A posteriori comparison was performed using the Student-NewmanKeuls (SNK) test. All statistical analyses were performed using Statistica v.8.0 (StatSoft).

\section{RESULTS}

\section{Wet weight and hepatosomatic index}

The ww of Octopus maya was not significantly different among sampling times (Table $1 ; p>0.05$ ). The hepatosomatic index (HSI) was higher in animals sampled 360 and 480 min after feeding compared with the other sampling times (Table 1, Fig. 1; $\mathrm{p}<$ 0.001). The ww of $O$. mimus specimens showed no significant differences among animals sampled throughout the experiment (Table $1 ; \mathrm{p}>0.05$ ). The HSI was higher at 270 and 330 min after feeding (Table 1, Fig. 1; $\mathrm{p}<0.001$ ).

Table 1. Wet weight of animals used to evaluate the digestive physiology of Octopus mimus and O. maya. n = number of animals sampled. Different letters indicate significant differences at the $\mathrm{p}<0.05$ level

\begin{tabular}{|c|c|c|c|c|c|c|}
\hline \multirow{2}{*}{$\begin{array}{l}\text { Time } \\
\text { (min) }\end{array}$} & \multirow[t]{2}{*}{$\mathrm{n}$} & \multicolumn{2}{|c|}{ Wet weight (g) } & \multicolumn{2}{|c|}{ HSI } & \multirow[t]{2}{*}{ Sig } \\
\hline & & Mean & SD & Mean & $\mathrm{SD}$ & \\
\hline \multicolumn{7}{|c|}{ Octopus maya } \\
\hline 0 & 6 & 893.5 & 481.5 & 2.60 & 0.20 & $\mathrm{a}$ \\
\hline 20 & 7 & 685.1 & 188.1 & 3.08 & 0.10 & $\mathrm{~b}$ \\
\hline 40 & 7 & 769.3 & 209.3 & 3.46 & 0.12 & $\mathrm{C}$ \\
\hline 80 & 7 & 954.3 & 517.6 & 2.54 & 0.15 & $\mathrm{a}$ \\
\hline 120 & 7 & 769.7 & 337.4 & 3.04 & 0.09 & $\mathrm{~b}$ \\
\hline 180 & 8 & 923.9 & 470.8 & 3.54 & 0.39 & $\mathrm{C}$ \\
\hline 240 & 10 & 797.4 & 414.7 & 3.30 & 0.22 & $\mathrm{C}$ \\
\hline 360 & 6 & 896.6 & 476.6 & 4.46 & 0.37 & $\mathrm{~d}$ \\
\hline 480 & 3 & 608.7 & 211.3 & 4.07 & 0.06 & d \\
\hline \multicolumn{7}{|c|}{ Octopus mimus } \\
\hline 0 & 5 & 987.20 & 275.78 & 2.98 & 0.30 & $\mathrm{a}$ \\
\hline 30 & 3 & 1056.50 & 163.53 & 3.00 & 0.41 & $\mathrm{a}$ \\
\hline 90 & 5 & 1171.20 & 121.64 & 2.98 & 0.29 & $\mathrm{a}$ \\
\hline 150 & 3 & 1159.20 & 137.71 & 3.01 & 0.28 & $\mathrm{a}$ \\
\hline 210 & 3 & 1002.23 & 81.57 & 2.58 & 0.14 & $\mathrm{a}$ \\
\hline 270 & 3 & 1094.67 & 272.58 & 3.84 & 0.48 & $\mathrm{~b}$ \\
\hline 330 & 3 & 992.53 & 179.23 & 4.11 & 0.29 & $\mathrm{~b}$ \\
\hline 390 & 3 & 948.87 & 158.70 & 3.55 & 0.42 & $a b$ \\
\hline
\end{tabular}

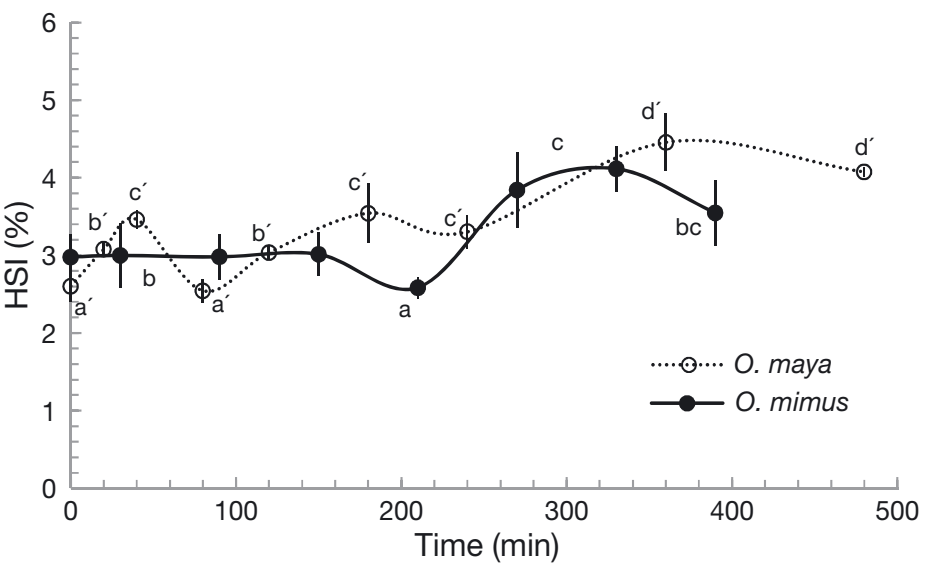

Fig. 1. Hepatosomatic index (HSI, \%) of Octopus maya and O. mimus during the digestion process. Values are means $\pm \mathrm{SD}$. In Figs. 1-5 \& 8, different letters indicate significant differences $(\mathrm{p}<$ 0.05 ) between sampling times. Letters for $O$. maya are distinguished by an apostrophe

\section{Extracellular digestion: chyme volume}

Chyme volumes varied along the digestive tract and throughout the digestion process in both species. In O. maya these changes were most evident in crop sections where 2 peaks were detected: one $20 \mathrm{~min}$ after feeding and another $120 \mathrm{~min}$ after feeding (Fig. 2; p < 0.001). In O. mimus, $50 \%$ of the GJ was recorded in the crop, $40 \%$ in the St and $10 \%$ in the Ce at the beginning of the experiment (Fig. 2).

\section{Soluble protein in chyme}

After feeding, the soluble protein concentration in the crop of $O$. maya was unchanged, increasing significantly until $80 \mathrm{~min}$ after feeding (Fig. $3 ; \mathrm{p}>0.05$ ). O. mimus had more soluble protein in the GJ in the crop before feeding compared with the other sampling times (Fig. $3 ; \mathrm{p}<0.001$ ). In addition, there were 2 peaks of soluble proteins in the St at 40 and $240 \mathrm{~min}$ in O. maya and at 30 and 150 min in O. mimus (Fig. 3; $\mathrm{p}<0.001$ ).

\section{Enzyme activity}

Extracellular digestion. Acidic and alkaline proteases showed 2 peaks at 40 and $180 \mathrm{~min}$ in $O$. maya (Fig. $4 ; \mathrm{p}<0.001$ ). In contrast, O. mimus showed one well-defined peak of acidic and one of alkaline protease activity along the digestive tract at 120 and 240 min after feeding, respectively (Fig. 4 ; p < 0.001). Activity of alkaline proteases in the stomach of $O$. 


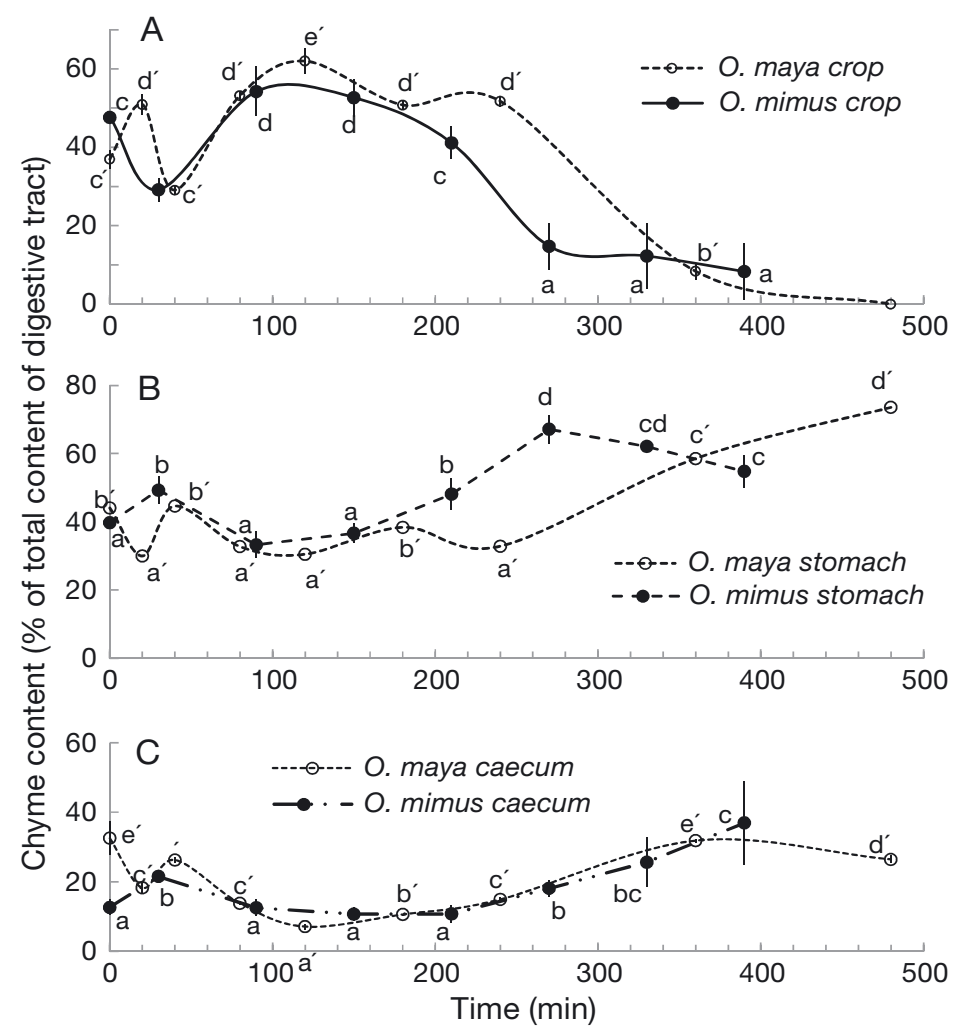

Fig. 2. Mean $( \pm \mathrm{SD})$ variation in chyme volume in the $(\mathrm{A})$ crop, (B) stomach, and (C) caecum of adult Octopus maya and O. mimus during the digestion process

mimus was marginal, with a small increase at the end of the digestive process (Fig. $4 ; \mathrm{p}<0.01$ ). In general, enzyme activity in the GJ measured along the digestive tract and during the digestive process was greater in O. mimus than in O. maya (Table 2).

Intracellular digestion in the digestive gland. Two peaks of acidic proteases were detected in the DG of $O$. maya at 0 and 360 min after feeding, whereas multiple peaks of alkaline proteases were also detected after feeding (Fig. $4 ; \mathrm{p}<0.01$ ). $O$. mimus had 2 peaks of acidic and alkaline proteases in the DG at 30 and 210 min after feeding (Fig. $4 ; \mathrm{p}<0.001$ ). Alkaline and acidic protease activity in DG measured during the digestive process was also greater in $O$. mimus than in $O$. maya (Table 3).

Soluble metabolites in the DG and hemolymph. Peaks of soluble metabolites in the DG of $O$. maya were followed by a decrease, or by stable levels of soluble metabolites in the hemolymph. Only glucose levels in the hemolymph registered similar peaks to those found in DG glycogen (Fig. 5 ; p < 0.001). In contrast, Soluble metabolites in $O$. mimus showed peaks in the DG that were followed by peaks in the hemolymph (Fig. 5 ; p < 0.001).
Plasma AA in O. maya. Essential (EAA) and non-essential (NEAA) amino acids showed 2 peaks. The first was observed 20 to $40 \mathrm{~min}$ after feeding and the second was detected 120 to 180 min after feeding (Fig. $6 ; \mathrm{p}<0.001$ ). The Factor 1 axis of the principal component analysis conducted using all AA data explained $63.8 \%$ of the total variance, correlating negatively $(\mathrm{p}<0.01)$ to isoleucine (Ileu), serine (Ser) and proline (Pro), and separating sampling times of 40,120 and 180 min after feeding. The Factor 2 axis explained only $17.7 \%$ of the variance, with lysine (Lys) separating the sampling times of 240 and 360 min after feeding (Fig. 7).

Muscle soluble protein and glycogen. Two peaks of soluble protein were detected in muscle samples from $O$. maya during the digestion process: one peak $40 \mathrm{~min}$ after feeding $(22.1 \mathrm{mg}$ $\mathrm{g}^{-1}$ ) and another peak 180 min after feeding $\left(20.6 \mathrm{mg} \mathrm{g}^{-1}\right.$ ) (Fig. 8; $\left.\mathrm{p}<0.005\right)$. In contrast, only 1 peak was recorded for muscle glycogen. $O$. mimus muscle glycogen had 2 peaks: one peak 270 min after feeding $\left(4.15 \mathrm{mg} \mathrm{g}^{-1}\right)$ and a second peak $390 \mathrm{~min}$ after feeding $\left(6.1 \mathrm{mg} \mathrm{g}^{-1}\right)$ (Fig. 8 ; $\mathrm{p}<0.001$ ).

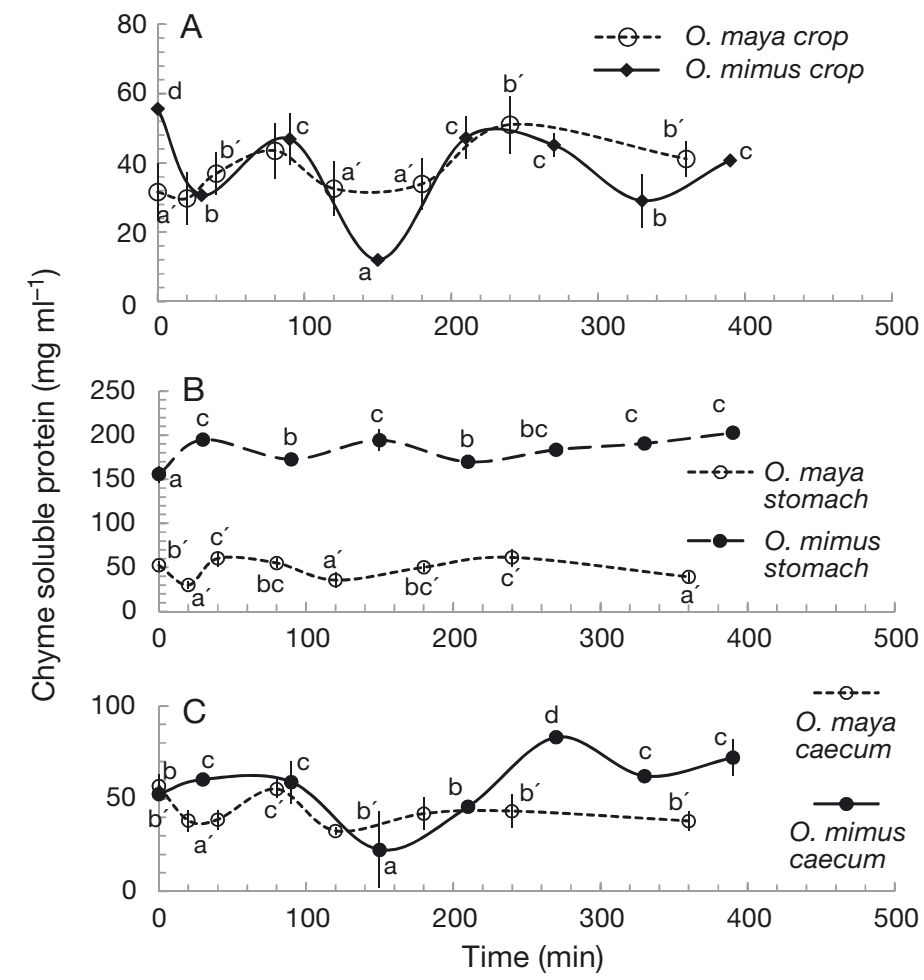

Fig. 3. Mean $( \pm \mathrm{SD})$ variation in soluble protein $\left(\mathrm{mg} \mathrm{ml}^{-1}\right)$ in the (A) crop, (B) stomach, and (C) caecum of adult Octopus maya and $O$. mimus during the digestion process 

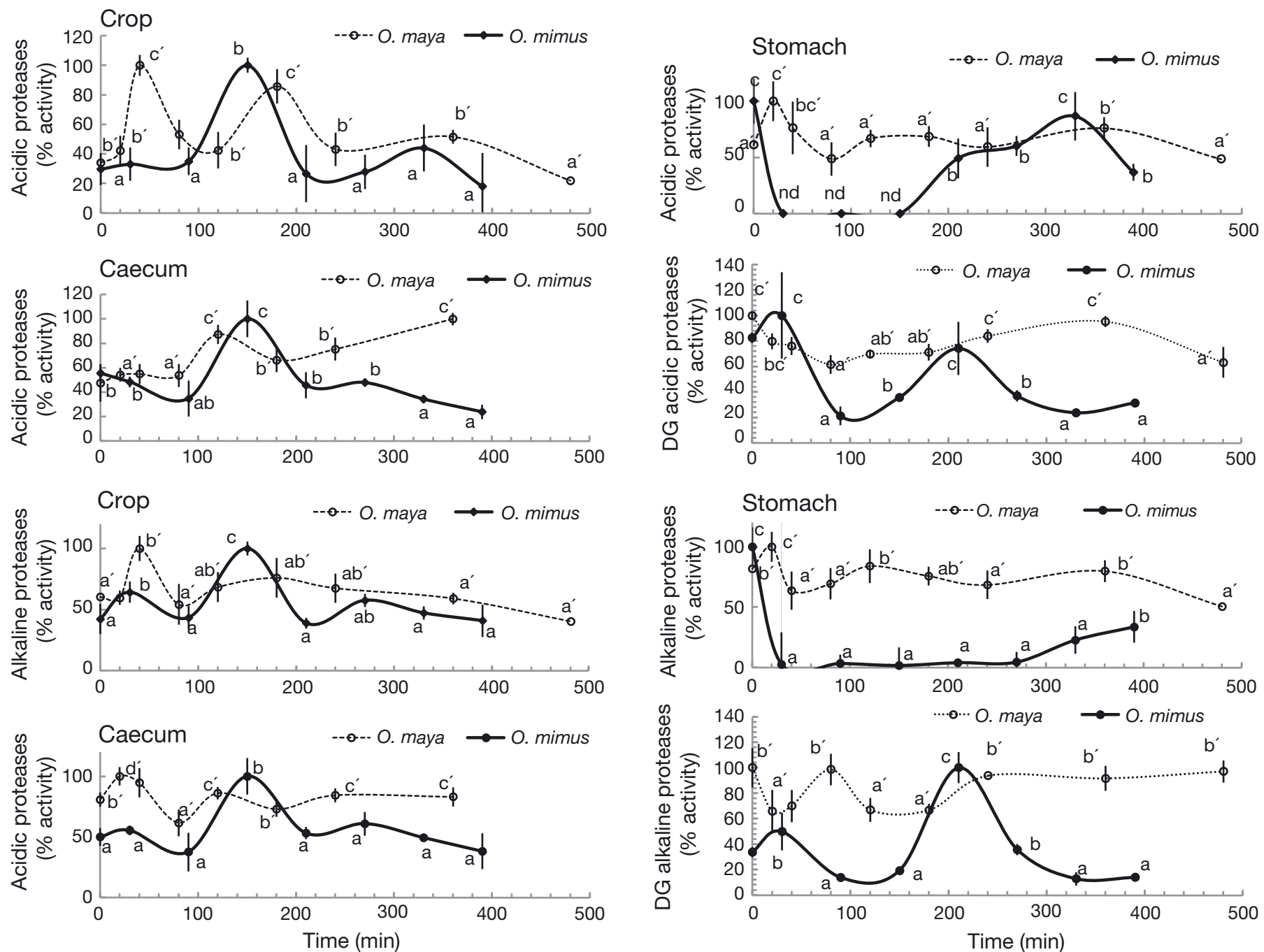

Fig. 4. Mean $( \pm \mathrm{SD})$ variations in gastric juice acidic and alkaline proteases (\% activity) along the digestive tract during the digestion process of adult Octopus maay and O. mimus. DG: digestive gland

\section{DISCUSSION}

We provide, for the first time, a detailed description of the digestion, absorption and assimilation of soluble and complex nutrients by tropical (i.e. Octopus maya) and subtropical-temperate (O. mimus) octopuses. We also provide valuable insights on the effect of environmental conditions on the digestion and final use of nutrients by these 2 species (Rosas et al. 2013), and presumably other species of octopods as well (Farías et al. 2011, Estefanell et al. 2012, Cerezo Valverde et al. 2013). The process of digestion begins when the digestive tract is ready to receive a meal. In this study, octopuses were fasted for $36 \mathrm{~h}$, which is sufficient time to guarantee that all experimental animals would ingest the meal when it was offered (George-Zamora et al. 2011).

\section{Extracellular digestion}

Our results indicated that $O$. maya and O. mimus prepared their digestive tracts for digestion. Digestive enzymes (zymogens) in the GJ were detected in the crop, St, Ce and DG before ingestion. At the same time, protein, AG and Chol levels in the hemolymph appeared to be at baseline levels, with nutrients maintaining the octopus during the fasting period. George-Zamora et al. (2011) showed that a fasting period of $10 \mathrm{~d}$ is totally reversible in O. maya as individuals use energetic AA to sustain their metabolism.

Octopuses immediately reacted to the offered food (crabs). We estimated that an individual O. maya of $\sim 900 \mathrm{~g}$ ww would need ca. 20 min to ingest a $100 \mathrm{~g}$ ww crab (Martínez et al. 2012), whereas a period of 
Table 2. Variations in gastric juice enzyme activity (general proteases, GP) along the digestive tract during the digestion process of adult Octopus maya and $O$. mimus. $\mathrm{ND}=$ not detected. Different letters indicate significant differences $(\mathrm{p}<0.05)$ between sampling times

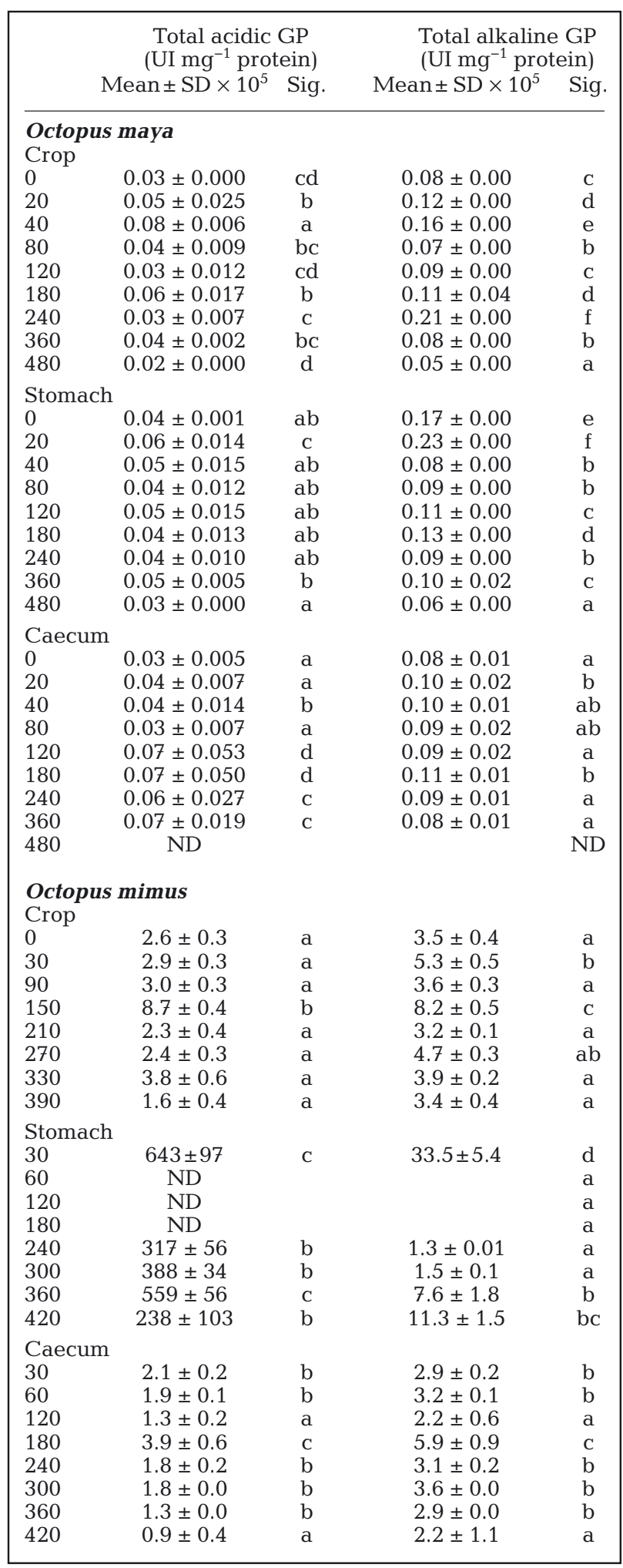

Table 3. Enzymatic activity (general proteases, GP) in the digestive gland evaluated during the digestive process in Octopus maya and O. mimus. Different letters indicate significant differences $(\mathrm{p}<0.05)$ between treatments

\begin{tabular}{|c|c|c|c|c|}
\hline & \multicolumn{2}{|c|}{$\begin{array}{l}\text { Total acidic GP } \\
\text { (UI } \mathrm{mq}^{-1} \text { protein) }\end{array}$} & \multicolumn{2}{|c|}{$\begin{array}{l}\text { Total alkaline GP } \\
\text { (UI } \mathrm{mg}^{-1} \text { protein) }\end{array}$} \\
\hline & Mean $\pm \mathrm{SD} \times 10^{5}$ & Sig. & Mean $\pm \mathrm{SD} \times 10^{5}$ & Sig. \\
\hline \multicolumn{5}{|c|}{ Octopus maya } \\
\hline 0 & $0.049 \pm 0.00$ & $\mathrm{C}$ & $2.1 \pm 0.5$ & $\mathrm{~b}$ \\
\hline 20 & $0.036 \pm 0.01$ & $\mathrm{bc}$ & $1.4 \pm 0.4$ & a \\
\hline 40 & $0.042 \pm 0.01$ & bc & $1.5 \pm 0.5$ & $\mathrm{a}$ \\
\hline 80 & $0.028 \pm 0.01$ & $\mathrm{a}$ & $2.1 \pm 0.9$ & $\mathrm{~b}$ \\
\hline 120 & $0.035 \pm 0.01$ & $\mathrm{ab}$ & $1.4 \pm 0.3$ & $\mathrm{a}$ \\
\hline 180 & $0.031 \pm 0.01$ & $a b$ & $1.4 \pm 0.2$ & $\mathrm{a}$ \\
\hline 240 & $0.042 \pm 0.01$ & $\mathrm{C}$ & $2.0 \pm 0.2$ & b \\
\hline 360 & $0.051 \pm 0.01$ & C & $1.9 \pm 0.2$ & $\mathrm{~b}$ \\
\hline \multicolumn{5}{|c|}{ Octopus mimus } \\
\hline 0 & $13.9 \pm 0.7$ & $\mathrm{C}$ & $6.5 \pm 0.8$ & b \\
\hline 30 & $16.8 \pm 5.7$ & $\mathrm{C}$ & $9.6 \pm 2.8$ & $\mathrm{~b}$ \\
\hline 90 & $3.6 \pm 1.3$ & $\mathrm{a}$ & $2.7 \pm 0.2$ & a \\
\hline 150 & $6.0 \pm 0.2$ & b & $3.7 \pm 0.3$ & $\mathrm{a}$ \\
\hline 210 & $12.5 \pm 3.5$ & $\mathrm{C}$ & $19.2 \pm 8.1$ & $\mathrm{C}$ \\
\hline 270 & $6.2 \pm 0.8$ & $\mathrm{~b}$ & $6.9 \pm 0.9$ & $\mathrm{~b}$ \\
\hline 330 & $4.0 \pm 0.6$ & a & $2.5 \pm 1.0$ & $\mathrm{a}$ \\
\hline 390 & $5.3 \pm 0.4$ & $\mathrm{a}$ & $2.7 \pm 0.1$ & $\mathrm{a}$ \\
\hline
\end{tabular}

30 min might be required for $O$. mimus to ingest the crab (Carrasco \& Guisado 2010). Martínez et al. (2012) observed that octopods inject saliva into their prey and wait for the enzymes contained in the saliva to open the prey (i.e. the crab). The chyme and partially digested flesh of the crab are then ingested, beginning the digestion process. Although this process is similar in both $O$. maya and $O$. mimus, our results indicate that external digestion is a more important process in $O$. mimus. A high concentration of soluble protein was recorded in the chyme of $O$. mimus, indicating that nutrients were quickly transported from the digestive tract to the DG where digestion started. It is interesting to note that lipid levels peaked in the DG of $O$. mimus before $O$. maya, suggesting that $O$. mimus may favor the digestion of lipids over proteins at the beginning of the digestion process. Differences in the digestion of lipids between the species could be related to the relationship between lipids and temperature. The geographic range of $O$. mimus includes temperatures between 15 and $21^{\circ} \mathrm{C}$, whereas $O$. maya lives in tropical zones where temperatures oscillate between 21 and $30^{\circ} \mathrm{C}$. The essentiality of $n-3$ highly unsaturated fatty acids (HUFA) in the diet of fish is directly related to the role of HUFA, as components of phospholipid biomembranes, in response to changes in environmental temperature (Tocher 2003). Such adaptation could occur in octopuses as well, allowing temperate spe- 

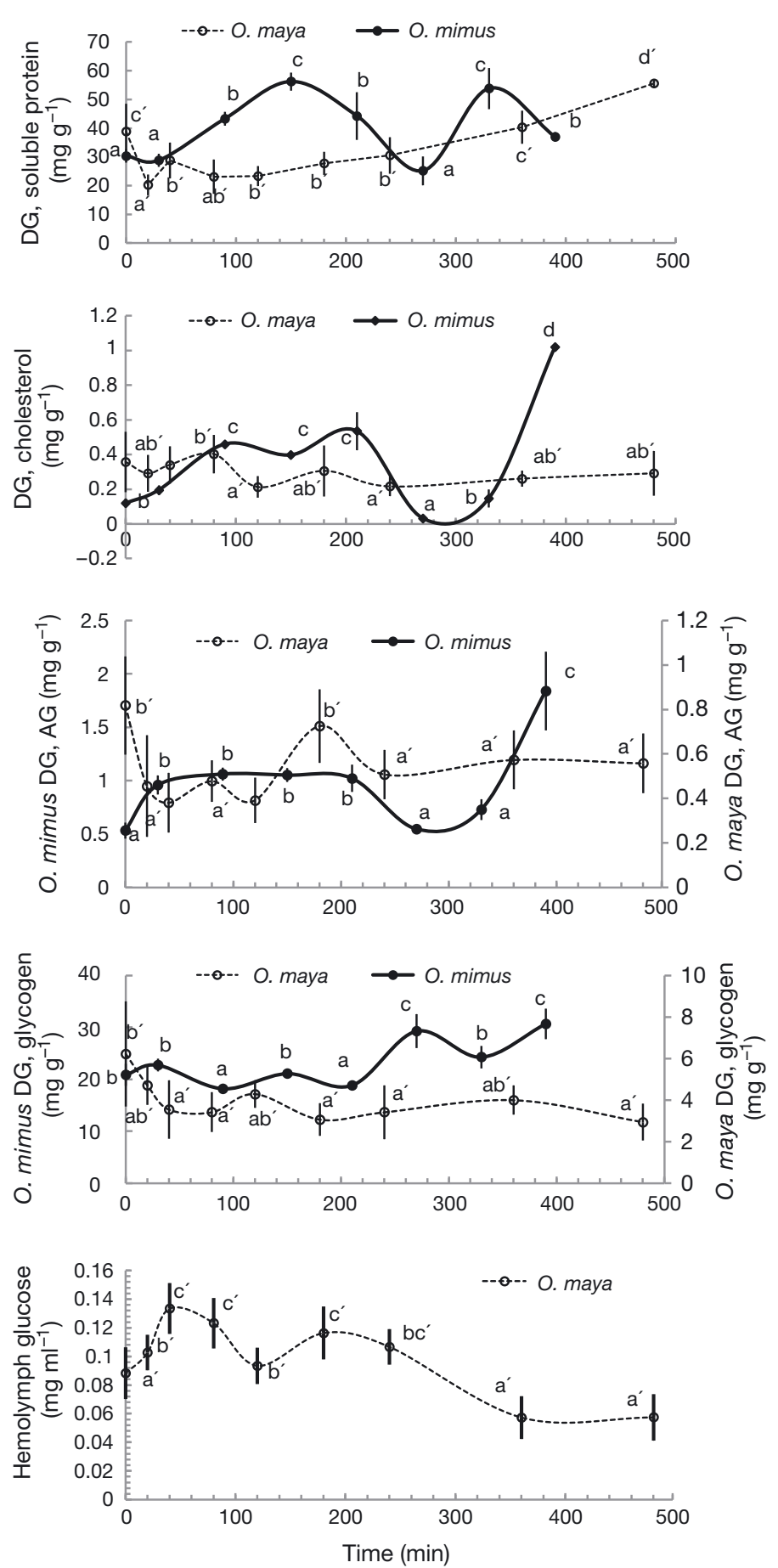

cies to use lipids in a different way than tropical octopuses. An increase in the demand for eicosapentanoic acid (EPA) and docosohexanoic acid (DHA) occurs in O. vulgaris maintained at low temperature $\left(15^{\circ} \mathrm{C}\right)$, indicating that these fatty acids (FA) are used for biomembrane synthesis during growth (Miliou et al. 2006). In contrast, the use of FA by $O$. vulgaris maintained at higher temperatures (i.e. 20 to $25^{\circ} \mathrm{C}$ )
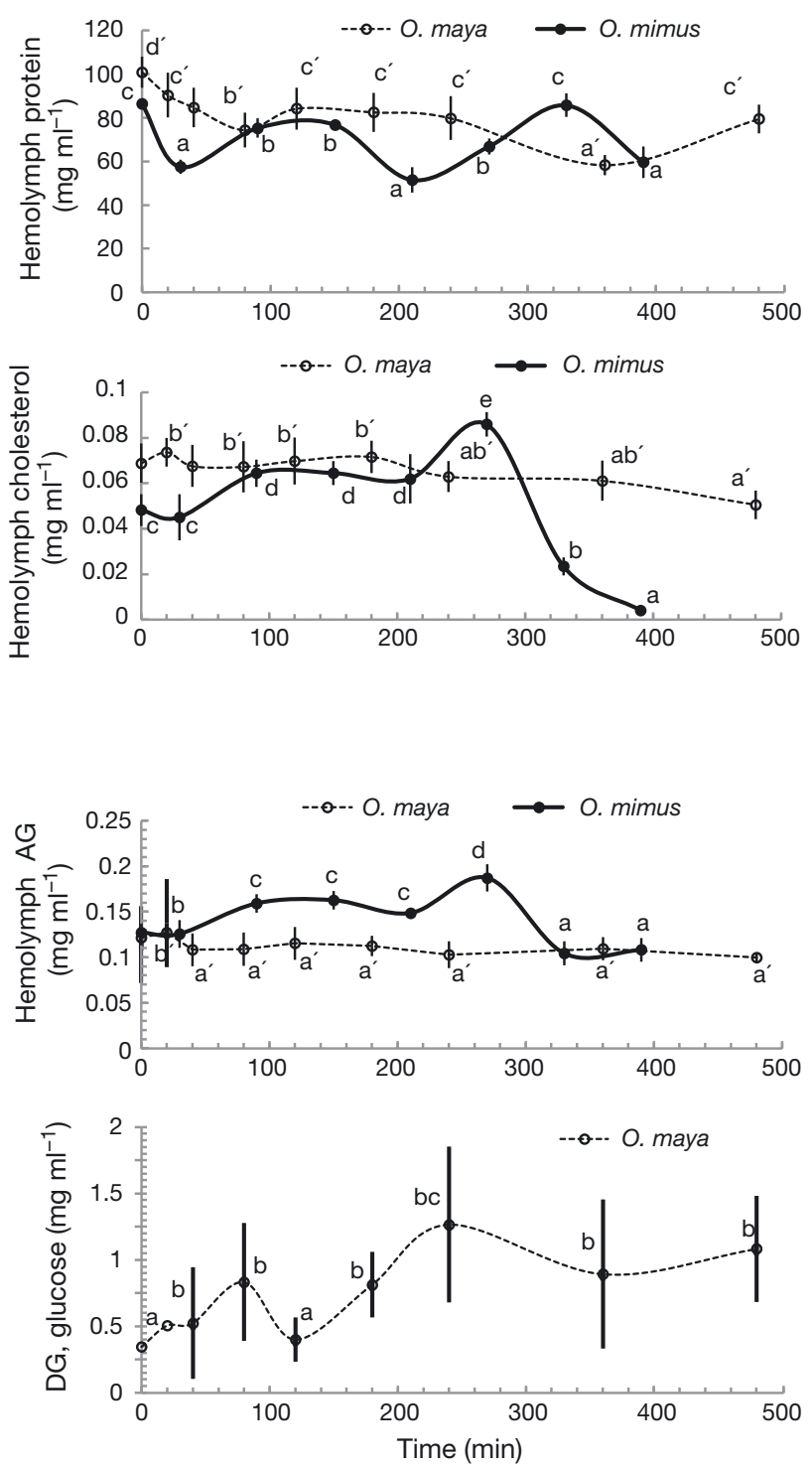

Fig. 5. Mean $( \pm \mathrm{SD})$ variations in digestive gland $(\mathrm{DG})$ and hemolymph of soluble protein, acylglycerols (AG), cholesterol, glycogen and glucose during the digestion process of adult Octopus maya and O. mimus

changes with temperature in an inverse relationship (Miliou et al. 2005).

We observed that the digestive processes occurred in 2 major steps: the first was characterized by soluble nutrients passing quickly along the digestive tract, where nutrients were absorbed and used for muscle protein synthesis. The second, slower step involved the digestion and transforma- 


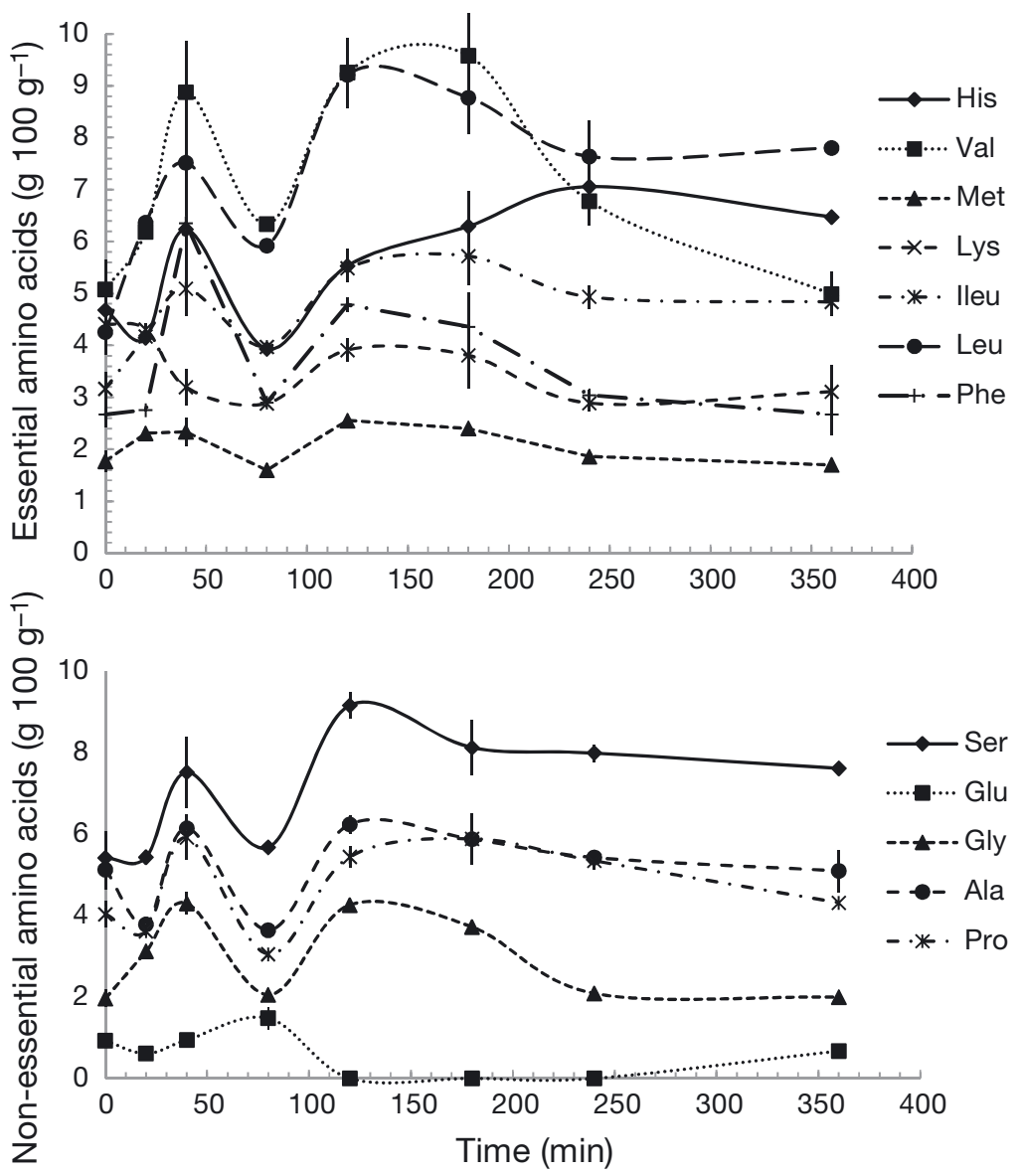

Fig. 6. Mean $( \pm \mathrm{SD})$ variations in hemolymph free amino acids during the digestion process of adult Octopus maya. His: histidine; Val: valine; Met: methionine; Lys: lysine; Ileu: Isoleucine; Leu: leucine; Phe: phenylalanine; Ser: serine; Gln: glutamine; Gly: glycine; Ala: alanine; Pro: proline

\section{Intracellular digestion}

Boucaud-Camou \& Boucher-Rodoni (1983) found that protein digestion in octopuses starts when the posterior salivary glands excrete enzymes that initiate the process of external digestion. We detected chymotrypsin activity in the posterior salivary glands of O. maya at the beginning of external digestion, which facilitates the digestion of soluble proteins before the ingestion of crabs (Aguila 2007). In both octopuses examined, the soluble proteins that form the chyme rapidly passed from the mouth to the DG after the external digestion process was initiated; soluble proteins then peaked in the crop, St and Ce 40 to 80 min after the octopuses were fed. The mechanism of action of the soluble protein in the chyme is unknown, but we hypothesize that it has several key roles, one of which could be to activate zymogens (acidic and alkaline enzymes) located in the crop and other sections of the digestive tract where zymogens are stored. Besides polypeptides, it is likely that enzymes injected during the ingestion of food are present in the chyme (Boucaud-Camou \& Boucher-Rodoni 1983, Hedstrom 2002). Indeed, zymogens have also been found in the digestive tract of other cephalopods. When studying the

tion of complex nutrients into useful molecules that were subsequently transported to muscles or temporarily stored in the DG. Despite the flow of soluble nutrients through the digestive tract into the DG, intracellular digestion in the DG of $O$. mimus was slower than in $O$. maya. Differences in the habitat temperatures of each species could affect the activity of digestive enzymes, slowing the digestive process in temperate species. It is interesting to note that the digestive enzyme activity in the GJ and DG of $O$. mimus was higher than that observed in O. maya. The slower digestion in temperate species may therefore be compensated for by high enzymatic activity, as has been observed in several fishes (Kuz'mina et al. 2015). In accordance with this finding, Pörtner (2006) suggested that temperate species tend to have more enzymes in order to counterbalance the high enzymatic activation energy required in temperate environments. cytological structure of the digestive gland during the feeding of Sepioteuthis lessoniana, Semmens (2002) observed that digestive enzymes were released after the first hours following feeding and concluded that these enzymes were stored in the stomach as zymogens to increase digestive efficiency. Our results suggest that the role of chyme as an activator of zymogens and other digestive processes can be extended at absorption sites, and can activate enzymes and reserve mobilization in the DG. With the first pulse of chyme, soluble proteins and amino acids could stimulate the brush wall of the cells in the octopus DG to absorb nutrients and activate endocytosis (Martínez et al. 2011a). It is not known how these mechanisms operate in octopuses; however, in terrestrial animals some free AA can facilitate the absorption of other AA, depending on the metabolic relationship between them or if specific AA are pre-loaded in the intestine (Herzberg \& Lerner 1973). The first pulse of chyme in O. maya and O. mimus may pre-load AA 

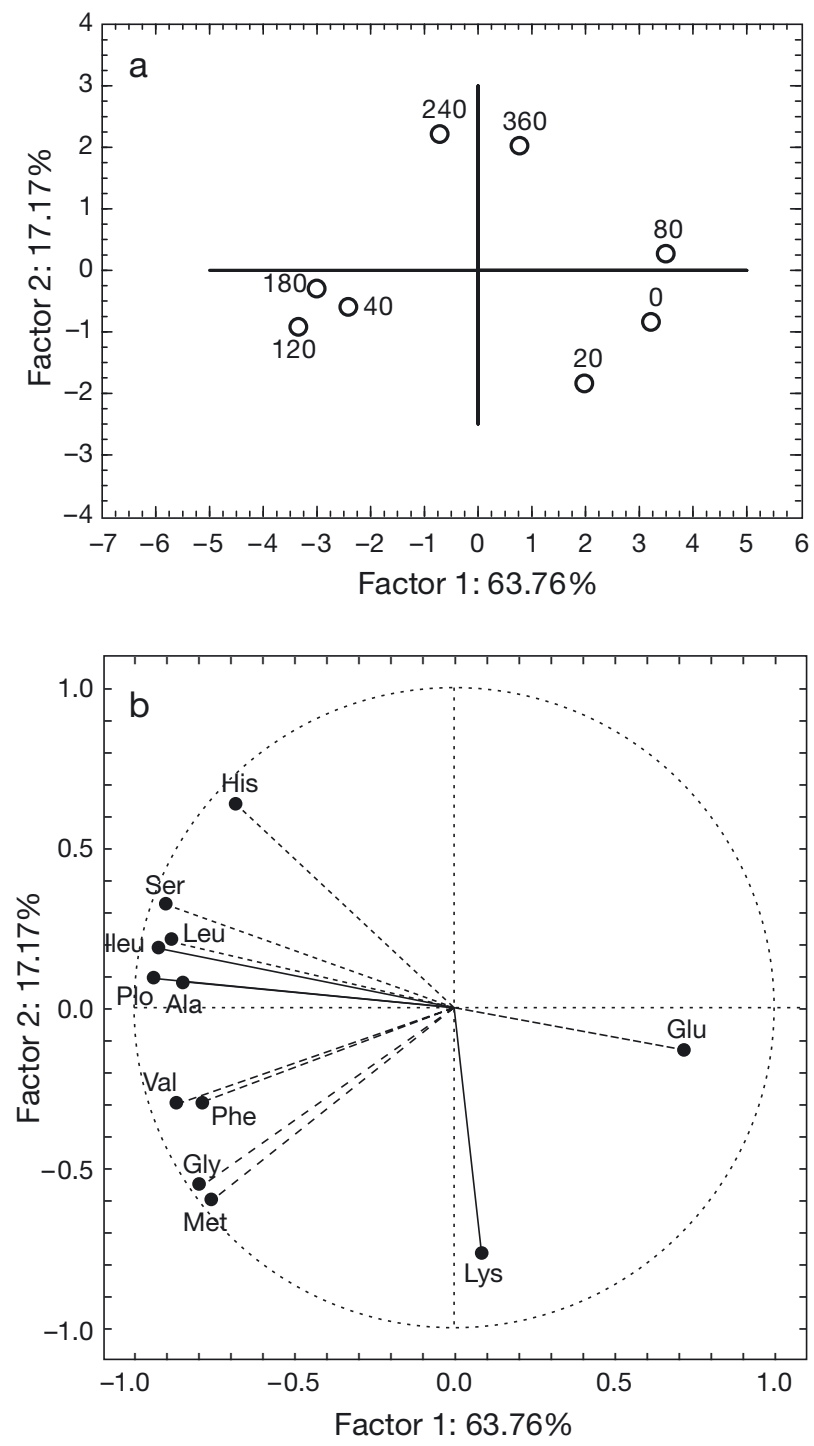

Fig. 7. Principal components analysis by cases (sampling time) and variables (amino acids) of hemolymph free amino acids obtained $(\mathrm{n}=3)$ during the digestion process in Octopus maya. Numbers indicate sampling time. Correlation analysis indicates that along the axis of Factor 1, Ileu (-0.93), Ser $(-0.90)$ and Pro $(-0.94)$ had a greater influence in the distribution of animals sampled at different times, placing animals sampled at 40,120, 180 min after feeding at the left of the Cartesian plane. The same analysis indicated that along the axis for Factor 2, Lys (-0.77) and His (0.64) were the amino acids responsible for the separation of animals sampled 20 min after feeding (down) and 240 and $360 \mathrm{~min}$ in after feeding (up) on the Cartesian plane. See Fig. 6 legend for amino acid abbreviations

and other nutrients to facilitate the absorption of the bulk of nutrients coming from the digestion of complex nutrients. To our knowledge, this is the first time that AA variations have been described during the digestion process in cephalopods.
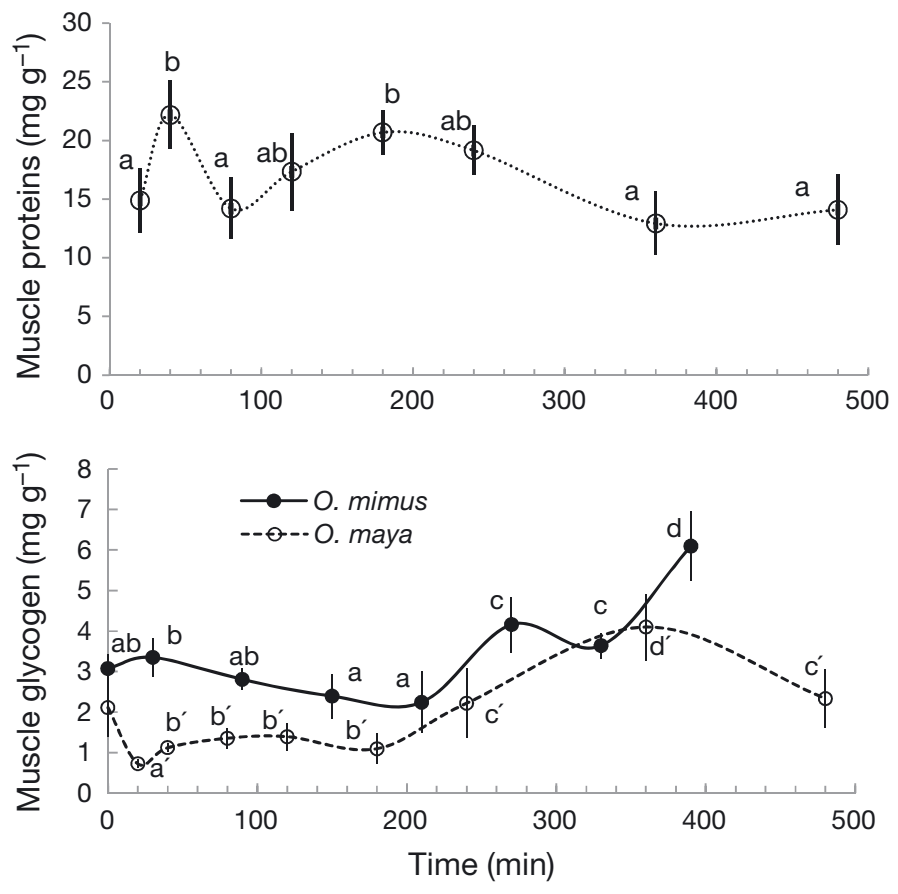

Fig. 8. Mean $( \pm \mathrm{SD})$ variations in muscle protein for Octopus maya and glycogen for $O$. mimus and $O$. maya during the digestion process

Morishita (1972) reported acidic enzymes in the crop, St and DG of O. vulgaris, describing for the first time the role of acidic proteases during digestion in an octopod. Acidic proteases were several times more active than alkaline proteases in $O$. maya and $O$. mimus. This finding supports previous studies suggesting that the main role of acidic protease (presumably cathepsines) in octopus digestion is as extracellular digestive protease (Martínez et al. 2011a, 2012). We observed that GJ enzyme activity in $O$. maya exhibited several peaks throughout the digestive process, indicating that the release of digestive enzymes from the DG occurred in 2 pulses (Semmens 2002, Martínez et al. 2012). Aside from the initial enzymes stored in the crop before digestion, there was only one peak of enzyme activity in the GJ of $O$. mimus, suggesting that there was only one more pulse of enzymes from the DG during the digestion process. These differences could be due to the environmental temperature at which each species was studied. Enzymes released to GJ appear to be more frequent in tropical species (e.g. O. maya) than in subtropical or temperate species (O. mimus). Therefore, temperature is likely to govern not only digestive activity through intracellular digestion in the DG, but also through enzyme production. 


\section{Nutrient metabolism}

Previous experiments performed with O. maya confirmed that animals fed with crab used ingested protein as a source of energy via the gluconeogenic pathway, which facilitated the accumulation of glycogen and its posterior release as glucose (Rosas et al. 2011, Martínez et al. 2012, Baeza-Rojano et al. 2013). In the present study, DG protein and glycogen levels in $O$. maya and $O$. mimus followed an inverse relationship throughout the digestive process, confirming the role of protein as a source of energy. These results suggest that glycogen accumulation must occur between meals, once the DG has recovered from the digestive process and nutrients are newly available for the next meal.

Soluble AG and Chol were also used as a source of energy for $O$. maya, whereas glycogen was the first source of energy for $O$. mimus. This is the first record detailing the role of soluble nutrients in the digestion process for both species examined. It is interesting that in O. maya, AG levels peaked once (180 min after feeding), whereas Chol peaked twice ( 80 and 180 min after feeding). These differences may be due to the form in which diverse nutrients were stored in the prey. AG are mainly stored in the DG and muscle of crustaceans (e.g Callinectes spp. or Cancer spp.; D'Abramo 1997), where octopus enzymes should be able to extract them. Our results suggest that AG appears in the DG when more complex nutrients are digested $180 \mathrm{~min}$ after feeding; for instance when AG was extracted from crab tissues. In crustaceans, Chol is an essential nutrient stored in the DG, muscle and hemolymph where it is mobilized and used as a precursor for molting and growth hormones (Teshima 1997, Pascual et al. 2003, Rosas et al. 2004, 2007a). The characteristics of Chol explain why this molecule showed 2 peaks in the O. maya DG, as it was obtained from the food on 2 occasions: from soluble nutrients in the first chyme pulse (probably soluble cholesterol found in the hemolymph and other tissues) and later, when more complex nutrients were digested. It is interesting to note that both nutrients were maintained in the DG, where they were presumably used as a source of energy, because neither of these nutrients was released into the blood during the digestion process. In fact, only hemolymph glucose levels changed significantly throughout the digestive process in $O$. maya and $O$. mimus. These molecules may therefore be mobilized as an energy source in muscle and other organs during the digestive process (Rosa et al. 2004, 2005a).

\section{Amino acid metabolism}

Following the chyme pulses, EAA and NEAA showed 2 peaks in $O$. maya hemolymph, indicating that there was AA flow during the first chyme pulse (40 min after feeding) and during the peak digestion of complex protein (140 to 180 min after feeding). Based on our results, we hypothesize that AA peaks were, at least in part, mobilized to be used for growth and glycogen synthesis in the muscle. Peaks of soluble protein observed at the same time as the AA peaks support this finding. Rosa et al. (2005a) demonstrated that AA, and in particular Pro and Arg, are the basis of energetic metabolism of pelagic, nektobenthic, benthic and benthopelagic cephalopods. Cephalopod muscle biochemistry includes complex mechanisms to use protein as a source of energy and for the accumulation of biomass at the same time (Boucaud-Camou \& Boucher-Rodoni1983). In cephalopods, as in other invertebrates, glycogen is mainly derived from dietary proteins, via amino acid metabolism (Rosas et al. 2002, Miliou et al. 2005). In the present study, we observed that glycogen peaks followed the peak of soluble protein, suggesting that these proteins were first synthesized from AA coming from the hemolymph to be used later as a source of energy via the gluconeogenesis pathway.

\section{CONCLUSIONS}

Although the flow of soluble nutrients through the digestive tract was similar in Octopus mimus and O. maya, intracellular digestion in the DG differed between these species. Whilst lipids were mobilized faster than proteins in O. mimus, proteins were mobilized faster than lipids in O. maya. This finding suggests that the mobilization of lipids in temperate octopuses is different from the metabolic process that occurs in tropical octopuses (Mukhin et al. 2007). The digestive enzyme activity in the GJ (mainly acidic proteases) and DG was greater in $O$. mimus than in $O$. maya. Adaptive differences may therefore be associated with the environmental temperatures in the regions where those species occur, which should be taken into account by the nutritionists who design dry foods for octopuses.

Acknowledgements. This study was financed by the CONACYT-CB201001 project No. 150810, by the bi-national Chile-Mexico cooperation agreement program of CONACYT granted to C.R. and O.Z., and by the PAPIIT-UNAM project: IT 2007-13-3 granted to P.G. M.L. was granted a 
CONACYT postgraduate studies fellowship. Thanks to the Posgrado en Ciencias del Mar at UNAM. Our greatest appreciation goes to DGCI-UNAM for the support provided to the international research group TEMPOXMAR. Thanks are given to Universidad de Antofagasta, Chile for supporting A.O. during his sabbatical year at UNAM facilities.

\section{LITERATURE CITED}

Aguado Giménez F, García García B (2002) Growth and food intake models in Octopus vulgaris Cuvier (1797): influence of body weight, temperature, sex and diet. Aquacult Int 10:361-377

Aguila J (2007) Bases nutricionales para el cultivo del pulpo Octopus maya. MSc dissertation, Universidad Nacional Autónoma de México, Mexico City

> Anson ML (1938) The estimation of pepsin, trypsin, papain, and cathepsin with hemoglobin. J Gen Physiol 22:79-89

> Baeza-Rojano E, Domingues P, Capella S, Noreña-Barroso E, Caamal-Monsreal C, Rosas C (2013) Marine gammarids (Crustacea: Amphipoda): a new live prey to culture Octopus maya hatchlings. Aquacult Res 44:1602-1612

Best EMH, Wells MJ (1984) The control of digestion in Octopus. II. The role of internal stimulus. Vie Milieu 34:1-7

Boucaud-Camou E, Boucher-Rodoni R (1983) Feeding and digestion in cephalopods. In: Saleuddin ASM, Wilbur KM (eds) The Mollusca. Academic Press, New York, NY, p 149-187

Boucaud-Camou E, Boucher-Rodoni R, Mangold K (1976) Digestive absorption in Octopus vulgaris (Cephalopoda: Octopoda). J Zool 179:261-271

Bradford MM (1976) A refined and sensitive method for the quantitation of microgram quantities of protein utilizing the principle of protein-dye binding. Anal Biochem 72: 248-254

Budelmann BU, Schipp R, Boletzky SV (1997) Cephalopoda. In: Harrison FW, Kohn A (eds) Microscopic anatomy of invertebrates, Vol 6A: Mollusca II. Willey-Liss, New York, NY, p 119-414

Carrasco S, Guisado C (2010) Effects of alimentary regime on feeding, growth, and proximal composition of Octopus mimus Gould, 1852 (Cephalopoda: Octopodidae). J Shellfish Res 29:455-461

Carroll NV, Langley RW, Roe JH (1956) The determination of glycogen in liver and muscle by use of anthrone reagent. J Biol Chem 220:583-593

> Cerezo Valverde J, Hernández M, García-Garrido S, Rodríguez C and others (2012) Lipid classes from marine species and meals intended for cephalopod feeding. Aquacult Int 20:71-89

Cerezo Valverde J, Martínez-Llorens S, Tomás A, Jover M and others (2013) Amino acids composition and protein quality evaluation of marine species and meals for feed formulations in cephalopods. Aquacult Int 21:413-433

D'Abramo LR (1997) Triacylglycerols and fatty acids. In: D'Abramo LR, Conklin DE, Akiyama DM (eds) Crustacean nutrition: advances in world aquaculture. World Aquaculture Society, Baton Rouge, LA, p 71-84

$>$ Dooley PC, Crouch P, West JM (2002) Free amino acids in claw muscle and haemolymph from Australian freshwater crayfish at different stages of the moult cycle. Comp Biochem Physiol A Mol Integr Physiol 131: 625-637

Estefanell J, Roo J, Guirao R, Afonso JM and others (2012)
Efficient utilization of dietary lipids in Octopus vulgaris (Cuvier 1797) fed fresh and agglutinated moist diets based on aquaculture by-products and low price trash species. Aquacult Res 44:93-105

- Farías A, Navarro JC, Cerna V, Pino S, Uriarte I (2011) Effect of broodstock diet on the fecundity and biochemical composition of eggs of the Patagonian red octopus (Enteroctopus megalocyathus Gould 1852). Cienc Mar $37: 11-21$

> George-Zamora A, Viana T, Rodriguez S, Espinoza G, Rosas C (2011) Amino acid mobilization and growth of juvenile Octopus maya (Mollusca: Cephalopoda) under inanition and re-feeding. Aquaculture 314:215-220-124

> Hedstrom L (2002) Serine protease mechanism and specificity. Chem Rev 102:4501-4524

Herzberg GR, Lerner J (1973) The effect of preloaded amino acids on lysine and homoarginine transport in chicken small intestine. Comp Biochem Physiol A Comp Physiol 44:1-16

Iglesias J, Fuentes L, Villanueva R (2014) Cephalopod culture. Springer, New York, NY

> Kuz'mina VV, Skvortsova EG, Shalygin MV, Kovalenko KE (2015) Role of peptidases of the intestinal microflora and prey in temperature adaptations of the digestive system in planktivorous and benthivorous fish. Fish Physiol Biochem 41:1359-1368

Martínez R, Santos R, Alvarez A, Cuzon G and others (2011a) Partial characterization of hepatopancreatic and extracellular digestive proteinases of wild and cultivated Octopus maya. Aquac Int 19:445-457

Martínez R, López-Ripoll E, Avila-Poveda O, Santos-Ricalde R, Mascaró M, Rosas C (2011b) Cytological ontogeny of the digestive gland in post-hatching Octopus maya, and cytological background of digestion in juveniles. Aquat Biol 11:249-261

- Martínez R, Santos R, Mascaró M, Canseco L, CaamalMonsreal C, Rosas C (2012) Digestive dynamics during chyme formation of Octopus maya (Mollusca, Cephalopoda). Aquacult Res 43:1119-1126

> Martínez R, Gallardo P, Pascual C, Navarro JC and others (2014) Growth, survival and physiological condition of Octopus maya when fed a successful formulated diet. Aquaculture 426-427:310-317

Mather JA, Anderson RC (2007) Ethics and invertebrates: a cephalopod perspective. Dis Aquat Org 75:119-129

Miliou H, Fintikaki M, Kountouris T, Verriopoulos G (2005) Combined effects of temperature and body weight on growth and protein utilization of the common octopus Octopus vulgaris. Aquaculture 249:245-256

> Miliou H, Fintikaki M, Tzitzinakis M, Kountouris T, Verriopoulos G (2006) Fatty acid composition of the common octopus, Octopus vulgaris, in relation to rearing temperature and body weight. Aquaculture 256:311-322

Moltschaniwskyj NA, Hall K, Lipinski MR, Marian JEAR and others (2007) Ethical and welfare considerations when using cephalopods as experimental animals. Rev Fish Biol Fish 17:455-476

> Morishita T (1972) Studies on the distribution of proteolytic enzymes in the internal organs of Octopus. Bull Jpn Soc Sci Fish 38:839-843 (in Japanese with English Abstract)

> Mukhin VA, Smirnova EB, Novikov VY (2007) Peculiarities of digestive function of proteinases in invertebratesinhabitants of cold seas. J Evol Biochem Physiol 43: 476-482

Nixon M (1979) Hole-boring in shells by Octopus vulgaris 
Cuvier in the Mediterranean. Malacologia 18:431-443

Nixon M (1980) The salivary papillae of Octopus as an accessory radula for drilling shells. J Zool 190:53-57

Noyola J, Caamal-Monsreal C, Díaz F, Re AD, Sánchez A, Rosas C (2013) Thermal preference, tolerance and metabolic rate of early juveniles of Octopus maya exposed to different acclimation temperatures. J Therm Biol 38: $14-19$

Olivares A, Zúñiga O, Castro G, Segura C, Sánchez J (1996) Bases biológicas para el manejo de Octopus mimus: reproducción y crecimiento. Estud Oceanol 15:61-74

Pascual C, Gaxiola G, Rosas C (2003) Blood metabolites and hemocyanin of the white shrimp Litopenaeus vannamei: the effect of culture conditions and a comparison with other crustacean species. Mar Biol 142:735-745

Perez-Losada MP, Guerra A, Sanjuan A (2002) Allozyme divergence supporting the taxonomic separation of Octopus mimus and Octopus maya from Octopus vulgaris (Cephalopoda: Octopoda). Bull Mar Sci 71:653-664

Porta J (2003) La formación del Istmo de Panamá. Su incidencia en Colombia. Rev Acad Colomb Cienc 27:191-216

Pörtner HO (2006) Climate-dependent evolution of Antarctic ectotherms: an integrative analysis. Deep-Sea Res II 53:1071-1104

Prato E, Portacci G, Biandolino F (2010) Effect of diet on growth performance, feed efficiency and nutritional composition of Octopus vulgaris. Aquaculture 309:203-211

Rosa R, Costa PR, Nunes L (2004) Effect of sexual maturation on the tissue biochemical composition of Octopus vulgaris and O. defilippi (Mollusca: Cephalopoda). Mar Biol 145:563-574

Rosa R, Costa PR, Bandarra N, Nunes AJP (2005a) Changes in tissue biochemical composition and energy reserves associated with sexual maturation in the ommastrephid squids Illex coindetii and Todaropsis eblanae. Biol Bull (Woods Hole) 208:100-113

Rosa R, Pereira J, Nunes ML (2005b) Biochemical composition of cephalopods with different life strategies, with special reference to a giant squid, Architeuthis sp. Mar Biol 146:739-759

Rosas C, Cuzon G, Gaxiola G, Pascual C and others (2002) An energetic and conceptual model of the physiological role of dietary carbohydrates and salinity on Litopenaeus vannamei juveniles. J Exp Mar Biol Ecol 268:47-67

Rosas C, Cooper EL, Pascual C, Brito R and others (2004) Indicators of physiological and immunological status of Litopenaeus setiferus wild populations (Crustacea, Penaeidae). Mar Biol 145:401-413

Rosas C, Cuzon G, Pascual C, Gaxiola G and others (2007a) Energy balance of Octopus maya fed crab and artificial diet. Mar Biol 152:371-378

Rosas C, Cooper EL, Pascual C, Brito R and others (2007b)

Editorial responsibility: Christine Paetzold,

Oldendorf/Luhe, Germany
Physiological and immunological conditions of wild populations of Farfantepenaeus duorarum from the Campeche Sound (Crustacea: Penaeidae). Mar Biol 152: 929-938

Rosas C, Sanchez A, Pascual C, Aguila y Elvira J, Maldonado T, Domingues P (2011) Effects of two dietary protein levels on energy balance and digestive capacity of Octopus maya. Aquacult Int 19:165-180

Rosas C, Valero A, Caamal-Monsreal C, Uriarte I and others (2013) Effects of dietary protein sources on growth, survival and digestive capacity of Octopus maya juveniles (Mollusca: Cephalopoda). Aquacult Res 44:1029-1044

Roura A, González A, Redd K, Guerra A (2012) Molecular prey identification in wild Octopus vulgaris paralarvae. Mar Biol 159:1335-1345

Salas S, Mexicano-Cíntora G, Cabrera M (2006) Hacia donde van las pesquerías de Yucatán? Tendencias, retos y perspectivas. Centro de Investigación y Estudios Avanzados, departamento de Recursos del Mar, Unidad Mérida, Mérida

Segawa S, Hanlon RT (1988) Oxygen consumption and ammonia excretion rates in Octopus maya, Loligo forbesi and Lolliguncula brevis (Mollusca: Cephalopoda). Mar Behav Physiol 13:389-400

Semmens JM (2002) Changes in the digestive gland of the loliginid squid Sepioteuthis lessoniana (Lesson, 1830) associated with feeding. J Exp Mar Biol Ecol 274:19-39

Stauffer CE (1989) Enzyme assay for food scientists. Van Nostrand Reinhold, New York, NY

Teshima S (1997) Phospholipids and sterols. In: D'Abramo L, Conklin DE, Akiyama DM (eds) Crustacean nutrition: advances in world aquaculture. World Aquaculture Society, Baton Rouge, LA, p 85-107

Tocher DR (2003) Metabolism and functions of lipids and fatty acids in teleost fish. Rev Fish Sci 11:107-184

Uriarte I, Espinoza V, Herrera M, Zuñiga O and others (2012) Effect of temperature on embryonic development of Octopus mimus under controlled conditions. J Exp Mar Biol Ecol 416-417:168-175

> Van Heukelem WF (1977) Laboratory maintenance, breeding, rearing and biomedical research potential of the Yucatan octopus (Octopus maya). Lab Anim Sci 27: 852-859

Villanueva R, Sykes A, Vidal AT, Rosas C and others (2014) Current status and future challenges in cephalopod culture. In: Iglesias J, Fuentes L, Villanueva R (eds) Cephalopod culture. Springer, New York, NY, p 479-489

Zar JH (1999) Biostatistical analysis. Prentice-Hall, Upper Saddle River, NJ

Zuñiga O, Olivares A, Ossandón L (1995) Influence of light in female sexual maturation of $O$. mimus. Estud Oceanol $14: 75-76$

Submitted: March 16, 2015; Accepted: November 2, 2015 Proofs received from author(s): December 17, 2015 